\title{
STRATEGI GURU AGAMA KRISTEN DALAM MEMBENTUK KARAKTER GENERASI MUDA DI ERA INDUSTRI 4.0
}

\author{
Edison $^{1} \&$ Talizaro Tafonao ${ }^{2}$ \\ Sekolah Tinggi Teologi Real Batam ${ }^{1 \& 2}$ \\ edison_pangareho@yahoo.com ${ }^{1}$, talizarotafonao@gmail.com ${ }^{2}$
}

\begin{abstract}
Abstrak
Kajian ini berangkat dari permasalahan yang sering terjadi di era industri 4.0. Di mana perilaku anak-anak muda saat ini banyak menimbulkan persoalan negatif di dalam masyarakat sebagaimana penjelasan data empiris dalam artikel ini. Salah satu karakter generasi muda yang dapat dilihat di era industri 4.0 adalah minimnya rasa kepedulian (individual) dan cenderung menentang nilai-nilai kebenaran dan kebudayaan yang berlaku. Tujuan penulisan artikel ini adalah melihat bagaimana upaya-upaya yang dilakukan oleh guru agama Kristen dalam membentuk karakter generasi muda sesuai dengan nilai-nilai Kristiani. Metode yang digunakan adalah metode kualitatif dengan mengkaji sejauh mana masalah yang timbulkan generasi muda di era industri 4.0. Proses analisis yang dilakukan adalah menggunakan berbagai sumber literatur seperti artikel jurnal, buku, dan pengamatan langsung untuk mendukung analisis penulisan. Hasil yang ditemukan adalah guru agama Kristen memiliki peran yang sangat signifikasi melalui upaya dan strategi serta pendekatan dalam membentuk karakter generasi muda di era revolusi industri 4.0 sebagaimana penjelasan dalam kajian artikel. Dengan demikian, tanggung jawab guru Agama Kristen dalam mendidik generasi sangat perlu direalisasikan sebagai wujud dari kepedulian terhadap fenomena yang ada di kalangan anak muda saat ini.
\end{abstract}

Kata kunci: Strategi, Guru, Kristen, Generasi, Karakter, Industri 4.0

\begin{abstract}
This study departs from problems that often occur in the industrial era 4.0, where the behavior of young people today causes many negative symptoms in social life in society. One of the characteristics of the younger generation that can be seen in the industrial era 4.0 is the lack of a sense of concern and tends to be individual and live in carelessness that always opposes the values of truth and prevailing culture. The purpose of writing this article is to see how the efforts made by Christian religious teachers in shaping the character of the younger generation in accordance with Christian values. The method used is a qualitative method by examining the extent of the problems caused by the character of the younger generation in the industrial era 4.0. The analysis process is carried out using various sources of literature, both articles, books, interviews and direct observations to support the author's analysis. The results found are significant about the role of Christian teachers supported by various strategies in shaping the character of the younger generation in the era of the industrial revolution 4.0. Thus, the responsibility of Christian Religion teachers in educating generations really needs to be realized as a form of concern for the phenomena that exist among young people as explained in this article.
\end{abstract}


Keywords: Strategy, Teacher, Christian, Generation, Character, Industry 4.0

\section{Pendahuluan}

Era industri 4.0 telah membawa perubahan dalam kehidupan setiap manusia. Menurut kajian yang dilakukan oleh Sawitri era industri 4.0 telah menghadirkan suatu tantangan baru kepada manusia, yakni digantikan dengan mesin atau robot. ${ }^{1}$ Dalam perjalanannya bahwa setiap tahapan revolusi tentu memiliki pengaruh dan dampak tersendiri. Dengan lompatan kemajuan ini, berbagai regulasi terbaru mewarnai kehidupan setiap manusia. Dengan kata lain, perkembangan ilmu dan teknologi telah memberi dampak positif dan negatif dalam segala aspek kehidupan, khususnya bagi generasi generasi $Z$.

Generasi $\mathrm{Z}$ adalah generasi yang lahir antara tahun 1995-2010 setelah generasi $\mathrm{Y}$, dan generasi ini disebut juga dengan Igeneration atau generasi internet. $^{2}$ Generasi ini sangat menikmati manfaat daripada teknologi itu sendiri. Artinya perkembangan ilmu dan teknologi memiliki dampak negatif dan positif, salah satu dampak negatif yang diamati oleh Tafonao, dkk, yakni anakanak muda lebih cenderung individual. ${ }^{3}$ Selain masalah tersebut, ada beberapa perilaku lain seperti anak-anak muda lebih banyak menghabiskan waktu untuk

\footnotetext{
${ }^{1}$ Dara Sawitri, "Revolusi Industri 4.0: Big Data Menjawab Tantangan Revolusi Industri 4.0," Jurnal Ilmiah Maksitek 4, no. 3 (2019): 15-27, https://makarioz.sciencemakarioz.org/index.php/JI M/article/view/83/80.

2 Yanuar Surya Putra, "Theoritical Review : Teori Perbedaan Generasi," Among Makarti 9, no. 2 (2017): 18-34.

3 Talizaro Tafonao, Sion Saputra, dan Rosita Suryaningwidi, "Learning Media and Technology: Generation Z and Alpha," Indonesian Journal of Instructional Media and Model 2, no. 2 (2020): 89-100.
}

bermain game online (ketergantungan). Novrialdy mengatakan aktifitas tersebut memiliki beberapa dampak, yakni: aspek kesehatan, psikologis, akademik, sosial, dan keuangan. ${ }^{4}$ Sedangkan dampak positif terhadap penggunaan teknologi atau gadget (smartphone) di kalangan generasi muda adalah menambah pengetahuan dengan berbagai informasi yang dapat diakses diberbagai situs. Sama dengan apa yang disampaikan oleh Achmad, dkk. dampak positif dalam menggunakan teknologi informasi yakni seseorang diberi kemudahan untuk melakukan berbagai interaksi yang tersedia seperti google, facebook, whatsapp, dan lainnya. ${ }^{5}$

Dengan menyingkapi hal di atas maka dipersiapkan sumber daya manusia yang berkualiatas dan berkarakter supaya dapat beradaptasi dengan perkembangan teknologi. Berdasarkan wawancara yang dilakukan oleh penulis kepada ke-enam orang tua dari anak-anak jemaat yang berusia 10-26 tahun pada tanggal $15 \mathrm{Mei}$ 2021 mengungkapkan bahwa, selama Covid-19 ini anak-anaknya lebih banyak menghabiskan waktu bermain game online selama 8 jam perhari. Artinya lebih sibuk dengan smartphonenya dari pada melakukan pekerjaan yang positif. Akibatnya anak-anak tersebut tidak ada rasa kepedulian, egois, malas-malasan dan sulit menerima nasihat dari orang tua bahkan gampang mengeluarkan kata-kata kotor. Menurut Rahmalah, dkk. bahwa, penggunaan gadget pada anak sangat berpengaruh pada karakter, di mana

\footnotetext{
4 Eryzal Novrialdy, "Kecanduan Game Online Pada Remaja: Dampak Dan Pencegahannya," Buletin Psikologi 27, no. 2 (2019): 148 - 158.

5 R Willya Achmad W et al., "Potret Generasi Milenial Pada Era Revolusi Industri 4.0," Focus : Jurnal Pekerjaan Sosial 2, no. 2 (2020): 187.
} 
ketika menggunakan gadget terus menerus, maka perilaku anak cenderung ke arah yang kurang baik. ${ }^{6}$

Dengan melihat problem di atas maka keterlibatan guru agama Kristen dalam mendidik dan membentuk karakter anak-anak muda di era industri 4.0 sangat penting. Sebagai guru agama Kristen dalam melakukan tugas pelayanan dan pengajar perlu adanya strategi, kreatif dan inovatif. Di dalam Alkitab ada banyak contoh bagaimana kehidupan generasi muda yang diajar oleh guru dengan menanamkan nilai-nilai kebenaran seperti yang dialami oleh Timotius. Timotius adalah pemuda biasa, sama seperti pemuda yang lain, tetapi dirinya bisa bertumbuh dalam karakter yang baik, karena sejak kecil dibentuk dan didik oleh lingkungan yang memiliki karakter yang baik pula.

Beberapa pribadi yang terlibat dalam mendidik karakter Timotius yaitu neneknya, ibunya, dan Paulus yang menjadi salah satu faktor utama dalam membentuk karakter dan kehidupan spiritual Timotius (2 Tim. 3:16-17). Menurut RG bahwa lembaga keluarga salah satu kunci utama dalam membentuk karakter generasi di era industri 4.0. ${ }^{7}$ Hal yang sama juga ditegaskan oleh Zega mengatakan bahwa orang tua memiliki tanggung jawab besar dalam mendidik anak-anak, agar memiliki pertumbuhan iman yang baik dan fungsi keluarga tidak

6 Prajnidita Zaeny Rahmalah et al., "Pengaruh Penggunaan Gadget Terhadap Pembentukan Karakter Anak Usia Dini," in Prosiding Seminar Nasional Lppm Ump, vol. 0, 2019, 302-310, https://semnaslppm.ump.ac.id/index.php/semnaslp pm/article/view/52/52\%0Ahttps://semnaslppm.um p.ac.id/index.php/semnaslppm/article/view/52.

${ }^{7}$ Salmawaty RG dan Hilal Mahmud, "Membentuk Karakter Generasi Muda Melalui Institusi Keluarga Di Era Digital," Kelola: Journal of Islamic Education Management 2, no. 2 (2017): 127-142. bisa digantikan oleh apapun. ${ }^{8}$ Demikan juga para guru-guru agama Kristen harus menyadari peranan sebagai guru yang dilandaskan pada pengertian akan firman Tuhan sebab guru pendidikan agama merupakan pelaksanaan Amanat Agung Kristus (Mat. 28:19-20) di Sekolah, ${ }^{9}$ sehingga apa yang di transfer kepada murid-murid dapat berdampak pada pertumbuhan dan karakter anak. Oleh sebab itu, seharusnya para guru tidak hanya puas dan melengkapi diri dalam bidang akademik.

Yunarti mempertegas bahwa tujuan pendidikan adalah untuk menciptakan manusia yang berkualitas dan berkarakter sehingga mampu beradaptasi secara cepat dan tepat dengan lingkungan yang ada, oleh karena itu, guru seharusnya memahami tujuan ini. ${ }^{10}$ Selanjutnya Tafanao memperkuat apa yang disampaikan oleh Yunarti di atas, bahwa menjadi guru harus benar-benar menjalankan tugas sebagai panggilan yang penuh tanggung jawab serta dedikasi yang tinggi dalam membentuk karakter generasi muda di era revolusi industri 4.0. ${ }^{11}$ Itu sebabnya, para guru perlu meperhatikan hal-hal ini dengan serius, karena hanya dengan pengajaran pengenalan akan Kristus anak-anak

\footnotetext{
8 Yunardi Kristian Zega, "Pendidikan Agama Kristen Dalam Keluarga: Upaya Membangun Spiritualitas Remaja Generasi Z," Luxnos 7, no. 1 (2021): 105-116.

9 Yunardi Kristian Zega, "Teori Perkembangan Iman Remaja Menurut James W.Fowler Dan Implikasinya Bagi Pendidikan Agama Kristen," Jurnal Pendidikan dan Kebudayaan Missio 12, no. 2 (2020): 140-151.

10 Yuyun Yunarti, "Pendidikan Kearah Pembentukan Karakter," Jurnal Ilmiah Pendidikan 11, no. 2 (2014): 262-278, http://ejournal.metrouniv.ac.id/index.php/tarbawiyah/arti cle/view/374.

${ }^{11}$ Talizaro Tafonao, "Peran Guru Agama Kristen Dalam Membangun Karakter Siswa Di Era Digital," Journal BIJAK Basileia Indonesian Journal of Kadesi 2, no. 1 (2018): 1-37.
} 
mengalami perubahan hidup sehingga dapat melahirkan karakter Kristiani yang dapat membedakan mana yang baik dan yang jahat (Rom 12:2).

Berdasarkan pokok permasalahan di atas, maka yang menjadi rumusan masalah tulisan ini adalah melihat sejauh mana strategi yang dilakukan oleh guru agama Kristen dalam upaya membentuk karakter generasi muda di era revolusi industri 4.0. Setelah memahami rumusan tersebut, maka tujuan penulisan ini adalah mendorong para guru agama Kristen untuk membentuk generasi muda sesuai dengan nilai-nilai Kristiani.

Banyak penelitian yang sudah membahas mengenai strategi guru agama Kristen dalam upaya membentuk karakter generasi muda di era industri 4.0, seperti Peran Guru Pendidikan Agama Kristen Dalam membentuk Karakter Siswa yang dilakukan oleh Situmorang, dkk. ${ }^{12}$ dan Telaumbanua ${ }^{13}$ yang menjelaskan tentang peran guru dalam membentuk karakter siswa di era industri 4.0 dan beberapa penelitian sebelumnya. Para penelitian ini sama-sama menjelaskan peran guru. Namun belum menjelaskan tentang strategi guru dalam membentuk karakter generasi muda di era induri 4.0. Oleh karena itu, artikel ini penting untuk dikaji dalam rangka memberikan edukasi mengenai strategi yang dilakukan oleh guru agama Kristen di era industri 4.0.

12 Ardianto Lahagu Kasminton Situmorang dan Benteng Martua Mahuraja Purba, "Peran Guru Pendidikan Agama Kristen Dalam Membentuk Karakter Siswa Di Era Industri 4.0," Institutio:Jurnal Pendidikan Agama Kristen 6, no. 2 (2020): 45-62.

13 Arozatulo Telaumbanua, "Peranan Guru Pendidikan Agama Kristen Dalam Membentuk Karakter Siswa," FIDEI: Jurnal Teologi Sistematika dan Praktika 1, no. 2 (2018): 219231.

\section{Metode}

Berdasarkan jenis data yang digunakan dan tujuan yang hendak dicapai, penelitian ini dikategorikan sebagai penelitian dengan pendekatan kualitatif deskriptif yang bertujuan untuk mempelajari makna yang disampaikan tentang masalah-masalah atau isu-isu penelitian seperti yang dikemukakan oleh Creswell. ${ }^{14}$ Penelitian kualitatif dilakukan untuk menjelaskan dan menganalisis fenomena, peristiwa, dinamika sosial, sikap kepercayaan, dan persepsi seseorang atau kelompok terhadap sesuatu. Proses analisis yang dilakukan adalah menggunakan berbagai sumber literatur baik artikel jurnal, buku, serta wawancara dan pengamatan langsung untuk mendukung analisis penulis.

\section{Hasil dan Pembahasan.}

\section{A. Peran Guru agama Kristen bagi generasi muda di era revolusi industri 4.0}

Membentuk karakter generasi muda di era revolusi industri 4.0 kerjasama dari berbagai pihak, seperti keluarga (orang tua), gereja dan lembaga pendidikan. Namun dalam tulisan ini, penulis menitipkan tanggung jawab itu kepada guru agama Kristen, karena itu guru agama Kristen sebagai orang yang sudah siap baik dari segi mental dan pengetahuan dapat memposisikan dirinya dalam upaya membentuk karakter generasi tersebut. Oleh sebab itu, ada beberapa hal yang harus diperhatikan oleh guru agama Kristen, antara lain:

Pertama, guru agama Kristen harus menjadi pemimpin yang berwibawa di era revolusi industri 4.0. Guru tidak hanya berbicara status dan kedudukan

\footnotetext{
14 J.W. Creswell, Research Design: Qualitative, Quantitative, and Mixed Method Approaches (Los Angeles: Sage Publicatio, 2009).
} 
melainkan lebih dari pada itu, di mana guru harus bisa menjadi pemimpin yang berwibawa bagi anak didiknya. Wibawa dalam hal ini adalah disegani dan dihormati oleh anak didik, guru yang tidak berwibawa menimbulkan kurang respect dari peserta didik sehingga jika situasi seperti ini dibiarkan akan mengganggu proses belajar dan timbul suasana kurang serius. Wibawa dapat ditunjukan dengan pengetahuan yang baik, sikap yang tegas bukan kasar, memiliki nama baik. Alkitab memberikan contoh bagaimana Abraham, Ishak, Yakub, Musa, Yosua, Daud, Petrus dan Rasul-rasul yang lain dan yang menjadi fokus dalam kepemimpinan Kristen adalah Yesus Kristus. Menurut Arianty, kepemimpinan adalah kemampuan memerintah dan mempengaruhi orang lain sehingga orang lain tersebut bisa mengerjakan sesuatu dengan penuh tanggung jawab dan mencapai tujuan yang diharapkan. ${ }^{15}$ Menurut hemat penulis, pemimpin yang berwibawa tidak harus berpenampilan gagah, kekar dan tampan, pemimpin yang berwibawa adalah pemimpin yang mampu memberi keteladanan hidupnya kepada orang lain termasuk generasi muda di era industri 4.0 ini.

Kedua, guru agama Kristen sebagai orang tua ketiga di era revolusi industri 4.0. Poin ini sangat berbeda dengan pemahaman orang pada umumnya termasuk tulisan-tulisan yang lainnya, biasa dikatakan bahwa guru adalah orang tua kedua bagi peserta didiknya. Penulis berpendapat bahwa orang tua pertama yang harus dipahami oleh anak-anak Kristen adalah Allah, prinsip ini harus ditanamkan sejak dini kepada anak-anak, bahwa mereka adalah anak Tuhan. Orang tua kedua adalah ayah dan ibu secara

15 Nel Arianty, "Pengaruh Kepemimpinan Terhadap Kinerja Kartawan," Jurnal Manajemen Tools 5, no. 2088-3145 (2015): 80-91. biologis dan orang tua ketiga bagi anakanak adalah guru di Sekolah. Oleh sebab itu, guru agama Kristen harus mampu memposisikan diri secara natural tanpa dibuat-buat menjadi orang tua ketiga bagi peserta didik, dengan memperlakukan setiap anak dengan hormat dan rasa kasih sayang serta berusaha menghilangkan halhal yang menjadi pembatas antara hubungan guru dengan peserta didik.

Menurut Amirullah, tugas guru tidak hanya menjelaskan ilmu pengetahuan dengan satu arah dalam mentransfer ilmu saja, melainkan memperhatikan dengan penuh perhatian, mengembangkan secara optimal potensi yang ada pada peserta didik. Hal ini dapat dilakukan jika guru dapat memposisikan dirinya sebagai orang tua. ${ }^{16}$ Penulis mengamati bahwa hal-hal seperti ini jarang dilakukan oleh guru, dimana guru hanya lebih fokus menyampaikan materi saja sesuai tuntutan kurikulum, tanpa melihat dan mempioritaskan hubungan yang dekat antara dirinya dan peserta didik. Didalam Alkitab Perjanjian Baru tepatnya di dalam 1 Tes. 2:7 Paulus mengatakan dia berlaku ramah seperti seorang ibu yang mengasuh dan merawat anak-anaknya, hal ini dilakukan terhadap Jemaat di Tesalonika untuk membawa perubahan hidup kepada Jemaat.

Bila diamati kisah kehidupan orang Tesalonika dalam Kitab Kisah Para Rasul 17, mereka bukan orang-orang yang baik apalagi orang Yahudi yang ada di sana, bahkan Paulus pernah membandingkan orang di Berea lebih baik hatinya dari pada orang Tesalonika. Tetapi semuanya itu berubah karena Paulus menyampaikan pengajaran sama seperti seorang Ibu kepada anak-anaknya dan hasilnya bisa lihat dalam 2 Tes 1 , dimana Paulus memberi pujian kepada

\footnotetext{
${ }^{16}$ Amrulloh Amrulloh, "Guru Sebagai Orang Tua Dalam Hadis 'Aku Bagi Kalian Laksana Ayah,"” Desember 2, no. 1 (2016): 70-91.
} 
jemaat tersebut karena memiliki perbertumbuhan dalam iman dan kasih. Berdasarkan cerita ini, penulis memiliki pandangan bahwa guru agama Kristen didalam menjalankan tugasnya sebagai guru harus bisa memposisikan dirinya sebagai orang tua kepada peserta didik dengan perilaku yang ramah dan penuh kasih sayang dalam menyampaikan pengajaran.

Ketiga, guru agama Kristen sebagai sahabat bagi generasi muda di era revolusi industri 4.0. Revolusi industri 4.0 adalah ditandai dengan kehidupan bebas dan mudah yang terintegrasikan dengan dunia teknologi (online). Tetapi hal ini memiliki kelebihan dan kekurangan, ada banyak hal-hal yang negatif yang dapat dirasakan oleh manusia, khususnya generasi muda yang tidak memiliki daya saing dalam menghadapi perubahan hidup di era revolusi industri 4.0. Generasi Z atau generasi yang lahir tahun 1995-2010 adalah generasi yang harus hidup di tengah-tengah perkembangan zaman yang semakin modern, seharusnya hal ini disyukuri karena bisa hidup di zaman yang serba cepat, tetapi samping itu ada ancaman, sebagaimana yang dijelaskan sebelumnya.

Menurut Poluakan, dkk, pada dasarnya perkembangan teknologi dapat memberikan manfaat bagi generasi saat ini, secara logika anak-anak sangat cepat beradaptasi, namun seiring berjalannya waktu terdapat miss presepsi terhadap pengunaan teknologi, oleh sebab itu perlu adanya edukasi dalam menerima manfaat dari teknologi itu sendiri. ${ }^{17}$ Akibat kurangnya edukasi maka banyak di kalangan remaja yang mengalami gangguan jiwa khususnya yang salah dalam menggunakan atau memanfaatka kemajuan teknologi. Disini letak peran

\footnotetext{
${ }^{17}$ W et al., "Potret Generasi Milenial Pada Era Revolusi Industri 4.0."
}

orang tua dalam mengawasi anak-anak, namun faktanya tidak seperti itu, orang tua banyak mengharapakan sekolah dalam mengarahkan anaknya. Sehingga mau tidak mau guru berperan sebagai orang tua dan sahabat. Guru agama Kristen berupaya menjadi sahabat bagi anak-anak didiknya, agar generasi ini tidak terpengaruh dengan isu-isu negatif dari perkembangan teknologi. Memposisikan diri sebagai sahabat tujuanya untuk melihat apa saja dilakukan oleh anak-anak muda di luar sana serta menjalin hubungan demi memberi kenyamanan sehingga anak-anak muda ini merasa didengar apa saja keluhannya. Dalam Injil Yohanes (Yoh. 15:14-15) Yesus sendiri mendefinisikan sahabat dan menjadikan dirinya sahabat bagi murid-murid-Nya, sehaingga ada hubungan yang dekat antar Yesus dengan murid-murid. Menjadi guru agama Kristen memang harus berbeda dengan guru-guru pada umumnya, guru agama Kristen harus dimaknai sebagai panggilan pelayanan. Menurut Telaumbanua, menjadikan diri sebagai sahabat artinya guru harus menjadi teman dan sahabat yang selalu terbuka dan membuka diri, dapat dipercayai, menjalin komunikasi yang baik dengan anak didiknya. ${ }^{18}$

Keempat, guru agama Kristen sebagai pelayan bagi generasi muda di era revolusi industri 4.0. Di dalam Alkitab tentunya kata pelayan tidak asing lagi untuk didengar, karena inilah yang ditekankan oleh Yesus dan Rasul-rasul. Dalam Injil misalnya Markus 10:43-45 ketika murid-murid sedang berdiskusi dan saling mengklaim dirinya adalah yang lebih besar, Yesus dengan suara yang lantang menjawab, barang siapa ingin menjadi besar hendaklah menjadi pelayanmu. Namun itu semua tidak hanya

18 Telaumbanua, "Peranan Guru Pendidikan Agama Kristen Dalam Membentuk Karakter Siswa." 
dikatakan oleh Yesus, tetapi ditunjukan langsung kepada murid-murid dalam Yohanes 13 ketika Yesus memposisikan diri-Nya sebagai pelayan dengan tujuan menanamkan nilai-nilai kepelayanan kepada para murid-murid.

Menurut Nakamanau, guru dapat memposisikan dirinya diberbagai tempat, guru adalah pribadi yang dapat dicontoh dalam kehidupannya, dalam hal ini guru bisa sebagai pengajar, fasilitator, gembala dan secara khusus guru sebagai pelayan. ${ }^{19}$ Penulis melihat hal ini bahwa hanya sedikit orang-orang yang mengerti dan mau memposisikan dirinya sebagai pelayan, apalagi jika orang tersebut memiliki jabatan dan kedudukan yang tinggi. Namun tidaklah demikian bagi semua guru agama Kristen, seperti yang sudah disampaikan di atas, bahwa guru agama Kristen harus bisa tampil beda dengan guru pada umumnya, guru agama Kristen harus dapat menyesuaikan diri dengan situasi dan kondisi yang ada.

Hal senada juga disampaikan oleh Telaumbanua, guru agama Kristen memiliki tugas yang kompleks dalam menjalankan profesinya sebagai pemimpin, pengajar dan pendidik. Artinya guru agama Kristen tidak hanya mengajar melainkan membimbing dan melayani muridnya, sama seperti Tuhan Yesus juga melayani. ${ }^{20}$ Penulis meyakini bahwa ketika guru agama Kristen menjalankan tugasnya dengan dasar-dasar yang ada didalam Alkitab, terutama menerapakan prinsip melayani dalam mengajar, maka guru agama Kristen dapat

\footnotetext{
19 Sriyanti Es Nakamnanu, "Shamayim: Jurnal Teologi Dan Pendidikan Kristiani Peran Guru Dalam Menerapkan Pendidikan Agama Kristen Untuk Menumbuhkan Iman Kristen Anak Sejak Dini," Jurnal Teologi dan Pendidikan Kristiani 1, no. 1 (2020): 14-28.

20 Arozatulo Telaumbanua, "Profil Guru Pendidikan Agama Kristen Sebagai Pemimpin Yang Melayai," Jurnal Teruna Bhakti 3, no. 1 (2020): 48.
}

leluasan dalam membentuk karakter generasi muda.

Menurut hemat penulis melayani berarti menolong atau membantu dengan penuh kesabaran, keikhlasan dan kasih sayang tanpa ada motivasi untuk mencari untung dan rugi, karena yang terpenting adalah orang yang dilayani bertumbuh di dalam iman. Contohnya guru agama Kristen tidak terpaku kepada gaji dan jam kerja sebagai guru serta tidak terbatas kepada jadwal di sekolah, melainkan guru agama Kristen harus memegang suatu prinsip bahwa pekerjaan ini adalah melayani Tuhan.

\section{B. Tantangan dalam membentuk karakter generasi muda di era revolusi industri 4.0}

Menurut Omer, karakter adalah kunci keberhasilan, karena karakter adalah modal utama dan penting untuk kemajuan suatu individu maupun bangsa. ${ }^{21}$ Oleh sebab itu, karakter sangat diperlukan dalam kehidupan setiap manusia khususnya generasi muda saat ini. Namun, membentuk karakter bagi generasi muda di era ini bukanlah sesuatu yang mudah, ada banyak tantangan di dalam prosesnya, apa lagi generasi saat ini sudah terlalu jauh masuk ke dalam keadaan yang sulit untuk keluar. Dengan kata lain, sebagian besar sudah kecanduan dengan hal-hal yang seharusnya tidak boleh dilakukan. Tantangan itu akan terasa jelas lagi jika dihubungkan dengan pendapat yang dikemukakan oleh Lickona yang mengatakan pendidikan karakter mencakup tiga hal yakni (1) mengetahui kebaikan (knowing the good), (2) mencintai kebaikan (desiring the good) dan (3) melakukan kebaikan (doing the

\footnotetext{
${ }^{21}$ Nopan Omer, "Pentingnya Pendidikan Karakter Dalam Dunia Pendidikan," manager pendidikan 9 (2015): 464-468.
} 
good). ${ }^{22}$

Penulis memperhatikan bahwa menanamkan ketiga hal di atas tidak mudah untuk dilakukan, karena anak-anak muda sekarang ini lebih banyak mendapatkan informasi dari berbagai media daripada mendapatkan informasi dari keluarga, sekolah dan gereja. Oleh sebab itu, tantangan terbesar yang dihadapi oleh guru agama Kristen dalam membentuk karakter di era industri 4.0 adalah pertama membawa generasi muda hudup mengenal Allah dan menjaga hubungan dengn Allah; kedua, guru menghadapi anak-anak muda yang egois atau mementingkan diri sendiri; ketiga, guru menghadapi anak-anak muda yang sudah diatur dan diarahkan. Dengan keadaan seperti ini maka guru agama Kristen membutuhkan waktu dan tenaga yang ekstra mendidik, membimbing dan mengajar.

\section{Strategi Guru Agama Kriseten dalam membentuk Karakter generasi muda di era revolusi industri 4.0}

Strategi adalah ilmu perencanaan dan penentuan arah dalam setiap kegiatan dan sejenisnya, strategi sangat diperlukan dalam menjalankan segala sesuatu jika hal itu dilakukan dengan maksimal. Menurut Tjiptono, istilah strategi berasal dari bahasa yunani strategia, stratos : militer dan $a g$ : memimpin, yang memiliki arti ilmu untuk menjadi seorang jenderal. Strategi bisa diartikan sebagai suatu rencana untuk pembagian dan pengunaan kekuatan militer dan material pada daerah-daerah tertentu untuk mencapai tujuan tertentu. ${ }^{23}$

22 Thomas Lickona, Pendidikan Karakter: Panduan Lengkap Mendidik Siswa Menjadi Pintar Dan Baik (Bandung: Nusa Media, 2013).

23 Fandy Tjiptono, Strategi Pemasaran (Yogyakarta: CV.Andi Offset, 2008).
Berdasarkan pendapat di atas dapat disimpulkan strategi adalah suatu langkah atau cara dalam melakukan kegiatan supaya terarah, tepat sasaran dan menuai hasil yang baik. Apa hubungannya dengan guru agama Kristen? Penulis berpandangan bahwa guru juga perlu menetapkan atau membuat strategi-strategi dalam mengajar anak-anak muda yang nantinya digunakan sebagai langkah dalam menjalankan kegiatan berkaitan dengan strategi yang relevan untuk membentuk karakter generasi muda di era revolusi industri 4.0. Menurut Hasbullah, pemilihan strategi yang tepat merupakan sesuatu yang sangat penting dipahami oleh pendidik. $^{24}$ Oleh karena itu, dalam menetapkan strategi mengajar, guru tidak bisa membuat strategi tersebut secara asal-asalan. Guru agama Kristen tidak hanya membuat RPP dengan mengkopi paste dari google dan hanya menganti kata-katanya saja. Tetapi dalam menetapkan dan membuat strategi harus dibuat dengan cermat dan dihubungkan dengan kebutuhan mengajar saat ini, supaya tepat sasaran dan dapat menghasilkan sesuatu yang baik.

Guru merupakan teladan bagi siswa dan memiliki peran yang sangat besar dalam pembentukan karakter generasi muda. Oleh karena itu, sebelum seorang guru terjun ke lapangan hal yang pertama yang harus dimiliki oleh guru adalah memiliki gaya hidup berdasarkan Alkitab dan hidup bijaksana serta gaya hidup yang dapat dicontoh oleh anak-anak muda. Menurut Poluakan dkk, mengutip kajian dari Larry dan Richard E. Potter, bahwa media sosial telah merubah cara pandang generasi muda dan merubah hal

\footnotetext{
${ }^{24}$ Hasbullah, Juhji, dan Ali Maksum, "Strategi Belajar Mengajar Dalam Upaya Peningkatan Hasil Belajar Pendidikan Agama Islam," Journal Pendidikan Agama Islam Edureligia 3, no. 1 (2019): 17-24.
} 
kepercayaan, nilai dan sikap. ${ }^{25}$ Hal seperti inilah yang harus diperhatikan oleh guru agama Kristen dalam menetapkan strategi dalam upaya membentuk karakter generasi muda di era revolusi industri 4.0, sehingga tepat sasaran dan dapat terima.

Berdasarkan penjelasan tersebut di atas maka, ada beberapa strategi yang perlu dibuat oleh guru agama Kristen dalam membentuk karakter generasi muda di era revolusi industri 4.0, antara lain: Pertama, guru agama Kristen perlu menanamkan gaya hidup rohani yang relevan dengan generasi muda. Lingkungan sosial yang jelek yang begitu masif mengancam kehidupan generasi muda termasuk dalam bermedia social. Tingkat penggunaan handphone/seluler pintar (teknologi) di kalangan generasi muda saat ini semakin tinggi seperti yang telah penulis sampaikan sebelumnya. Menurut Ahmad, anak muda sekarang ini sangat susah jauh dengan media sosial. ${ }^{26}$ Bahkan penulis sering mendengar dari kalangan anak muda suatu ucapan "hidup ini terasa hampa tanpa ada handphone dan media sosial." Seperti yang dilihat oleh penulis pada saat pulang kampung di daerah Kalimantan Barat, di sana tidak ada jaringan, jika ada pun harus mencari jaringan menempuh perjalanan sekitar 1-2 KM dan harus naik gunung. Sekalipun hal ini jauh namun anak-anak muda di kampung tersebut tetap menempuh apapun kondisinya. Selama penulis mengamati 2-3 kali naik ke gunung untuk mencari sinyal, tidak ada keperluan lain selain bermedia sosial. Apakah ini salah? Sebenarnya ini bukan tentang salah dan benar, ini lebih kepada apa manfaatnya dan dampaknya? Jadi bagaimana mengatasi masalah tersebut? Menurut

${ }^{25}$ W et al., "Potret Generasi Milenial Pada Era Revolusi Industri 4.0."

${ }^{26}$ Amar Ahmad, "Media Sosial Dan Tantangan Masa Depan Generasi Milenial," Avant Garde 8, no. 2 (2020): 134. hemat penulis tidak mudah mengatasi halhal di atas, tetapi guru agama Kristen memiliki tanggung jawab memberi kesadaran kepada generasi muda tentang nilai-nilai hidup yang benar berdasarkan Alkitab. Didalam Roma 12:1-2 tentang nasihat Paulus, dimana langkah awal adalah pengenalan akan Tuhan, karena tidak mungkin orang mempersembahkan hidupnya kepada Tuhan dan beribadah kepada-Nya tanpa pengenalan akan Tuhan terlebih dahulu. Dalam hal ini guru agama Kristen harus mampu membawa generasi muda kepada pengenalan akan Tuhan. Langkah ini tidak bermaksud memisahkan generasi muda dengan perkembangan teknologi itu sendiri, tetapi menanamkan budaya hidup rohani supaya dapat membedakan mana yang baik dan benar. Menurut kajian Rotto, permaslahan yang dialami oleh generasi muda adalah tidak mampu menempatkan diri di lingkungan sekitar. Oleh sebab itu, pertumbuhan rohani sangatlah penting bagi generasi muda, supaya dapat mengenal yang baik dan yang tidak bermanfaat. $^{27}$

Kedua, guru agama Kristen menanamkan pengertian yang baik tentang teknologi. Generasi muda di era revolusi industri 4.0 tidak dapat lagi dipisahkan dengan teknologi, apapun cara yang digunakan orang tua dan guru. Jadi langkah guru agama Kristen bukan memisahkan generasi muda dengan perkembangan zaman dan lingkungan media sosial, melainkan menanamkan nilai kebermanfaatan dari media teknologi tersebut. Menurut hemat penulis dalam menghadapi kondisi seperti ini, guru agama Kristen bukan melarang, melainkan lebih kepada memberi pengetahuan, mengajarkan nilai-nilai

\footnotetext{
27 Marinus Rotto, "Pemuridan Kontekstual Terhadap Pertumbuhan Rohani Pemuda Masa Kini," Journal of Chemical Information and Modeling 53, no. 9 (2013): 1689-1699.
} 
hidup benar dalam memanfaatkan teknologi itu sendiri. Dengan kata lain, teknologi dapat dijadikan sebagai sarana untuk memuliakan Tuhan. Ada banyak ayat-ayat Alkitab yang bisa dijadikan sebagai renungan seperti dalam Surat Kolose 3:23 Apapun yang kamu perbuat, perbuatlah dengan segenap hati, seperti untuk Tuhan bukan untuk manusia. Tulisan rasul Paulus ini bisa membuka pengertian generasi muda untuk melakukan sesuatu harus didasarkan pada kebenaran. Apapun yang dikerjakan sangat berdampak pada kehidupan sekarang ini dan kehidupan pada kekekalan (abadi). Menurut Sumolang, internet (teknologi) ini sangat bermanfaat bagi manusia. ${ }^{28}$ Dari sini dapat dipahami bahwa teknologi perlu dimanfaatkan seabagai sarana dalam berintraksi kepada orang. Ini tugas dan tanggung jawab guru agama Kristen dalam menjelaskan manfaat dari media sosial tersebut. Tetapi dalam menghadapi hal ini menurut Zahroh sangat dibutuhkan pribadi yang berkarakter. $^{29}$

Ketiga, guru agama Kristen menyediakan waktu tambahan diluar jam sekolah untuk mengunjungi anak-anak. Tujuan kegiatan ini adalah untuk mengetahui tentang persoalang apa yang sedang dialami oleh anak-anak muda saat ini. Dengan adanya tambahan tersebut maka guru dapat lebih mengenal tentang karakter dan kebiasaan anak-anak muda di luar jam sekolah. Karena jadwal di sekolah sangat terbatas dalam belajar, jika diperhatikan jadwal pertemuan di kelas

28 Marcelino Sumolang, "Peranan Internet Terhadap Generasi Muda Di Desa Tounelet Kecamatan Langowan Barat," The Internet for Surgeons 2, no. 4 (2013): 52-57.

29 Shofiyatuz Zahroh dan Na'imah Na'imah, "Peran Lingkungan Sosial Terhadap Pembentukan Karakter Anak Usia Dini Di Jogja Green School," Jurnal PG-PAUD Trunojoyo: Jurnal Pendidikan dan Pembelajaran Anak Usia Dini 7, no. 1 (2020): $1-9$. khususnya saat pelajaran agama Kristen hanya ada satu kali pertemuan dalam satu minggu, seperti yang dialami oleh anak penulis sendiri, di mana jadwal belajar agama hanya setiap hari jumat ada jam belajar agama kurang lebih 3-4 jam. Menurut Lestari, waktu sangat berpengaruh dalam proses belajar, pengunaan waktu yang tepat dan waktu yang cukup dapat membuat pembelajaran tersebut lebih efektif. ${ }^{30}$

Penulis berpendapat guru agama Kristen harus bisa memahami hal ini, bahwa waktu di sekolah tidak cukup untuk menghasilkan pembelajaran dengan baik. Menurut penjelasan Saputri, proses pembelajaran secara formal di sekolah sering kali dipandang tidak cukup karena dibatasi oleh waktu, oleh karena itu perlu ada waktu tambahan untuk dapat memahami dan mengulangi pembelajaran yang belum jelas dari sekolah. ${ }^{31}$ Menurut hemat penulis ada banyak manfaat ketika guru mengunjungi murid-murid di rumahnya, selain dekat dengan murid, guru juga bisa dekat dengan keluarga anak-anak muda sehingga dapat berbagi informasi dan bekerja sama untuk kemajuan pembelajaran anak tersebut. Contoh dalam Alkitab adalah Yesus, selama Dia memilih para murid untuk mengikuti pelayanan-Nya, Yesus selalu bersama-sama dengan murid-murid-Nya, kebersamaan itulah Yesus melatih untuk bertumbuh. Demikian seharusnya guruguru agama Kristen, melakukannya bahwa panggilan pelayanan, lebih

\footnotetext{
${ }^{30}$ Indah Lestari, "Pengaruh Waktu Belajar Dan Minat Belajar Terhadap Hasil Belajar Matematika," Formatif: Jurnal Ilmiah Pendidikan MIPA 3, no. 2 (2015): 115-125.

${ }^{31}$ Oktaviani Dwi Saputri dan Rahmawati, "Peran Guru Dalam Memberikan Pelajaran Tambahan (LES) Bagi Peserta Didik Di Luar Jam Pelajaran Sekolah Sebagai Wujud Implementasi Pengabdian Kepada Masyarakat," Prosiding Seminar Nasional Pendidikan Program Pascasarjana Universitas PGRI Palembang 2 (2019): 493-504.
} 
banyaklah waktu bersama dengan murid.

\section{Kesimpulan}

Berdasarkan hasil kajian dalam tulisan ini, penulis melihat bahwa perkembangan teknologi sangat berpengaruh negatif pada karakter generasi muda di era industri 4.0. Oleh karena itu, keterlibatan guru agama Kristen dalam menghadapi tantangan tersebut sangat diperlukan, karena salah satu tujuan pendidikan agama Kristen adalah membentuk dan menciptakan generasi-generasi muda yang berkarakter sesuai dengan nilai-nilai Kristiani. Dengan mencapai dan menjawab harapan tersebut maka guru agama Kristen harus memiliki jiwa membina, mendidik, dan melayani sebagaimana yang telah dijelaskan dalam artikel ini. Kajian ini menjadi salah satu kontribusi bagi para guru Agama Kristen dan pelayan Tuhan di gereja serta para aktivis pendidik dalam melihat berbagai fonomena yang terjadi saat ini di kalangan generasi muda. Selain itu, tulisan ini menjadi sumbangsih pemikiran baru bagi para peneliti berikutnya dalam mengembangkan model pembelajaran yang sesuai dengan kebutuhan generasi muda di era industri 4.0.

\section{Referensi}

Ahmad, Amar. "Media Sosial Dan Tantangan Masa Depan Generasi Milenial." Avant Garde 8, no. 2 (2020): 134.

Amrulloh, Amrulloh. "Guru Sebagai Orang Tua Dalam Hadis 'Aku Bagi Kalian Laksana Ayah."' Desember 2, no. 1 (2016): 70-91.

Arianty, Nel. "Pengaruh Kepemimpinan Terhadap Kinerja Kartawan." Jurnal Manajemen Tools 5, no. 2088-3145 (2015): 80-91.

Creswell, J.W. Research Design:
Qualitative, Quantitative, and Mixed Method Approaches. Los Angeles: Sage Publicatio, 2009.

Dwi Saputri, Oktaviani, dan Rahmawati. "Peran Guru Dalam Memberikan Pelajaran Tambahan (LES) Bagi Peserta Didik Di Luar Jam Pelajaran Sekolah Sebagai Wujud Implementasi Pengabdian Kepada Masyarakat." Prosiding Seminar Nasional Pendidikan Program Pascasarjana Universitas PGRI Palembang 2 (2019): 493-504.

Fandy Tjiptono. Strategi Pemasaran. Yogyakarta: CV.Andi Offset, 2008.

Hasbullah, Juhji, dan Ali Maksum. "Strategi Belajar Mengajar Dalam Upaya Peningkatan Hasil Belajar Pendidikan Agama Islam.” Journal Pendidikan Agama Islam Edureligia 3, no. 1 (2019): 17-24.

Kasminton Situmorang, Ardianto Lahagu, dan 2Benteng Martua Mahuraja Purba. "Peran Guru Pendidikan Agama Kristen Dalam Membentuk Karakter Siswa Di Era Industri 4.0." Institutio:Jurnal Pendidikan Agama Kristen 6, no. 2 (2020): 45-62.

Lestari, Indah. "Pengaruh Waktu Belajar Dan Minat Belajar Terhadap Hasil Belajar Matematika." Formatif: Jurnal Ilmiah Pendidikan MIPA 3, no. 2 (2015): 115-125.

Lickona, Thomas. Pendidikan Karakter: Panduan Lengkap Mendidik Siswa Menjadi Pintar Dan Baik. Bandung: Nusa Media, 2013.

Marcelino Sumolang. "Peranan Internet Terhadap Generasi Muda Di Desa Tounelet Kecamatan Langowan Barat." The Internet for Surgeons 2, no. 4 (2013): 52-57.

Marinus Rotto. "Pemuridan Kontekstual Terhadap Pertumbuhan Rohani Pemuda Masa Kini." Journal of 
Chemical Information and Modeling 53, no. 9 (2013): 1689-1699.

Nakamnanu, Sriyanti Es. "Shamayim: Jurnal Teologi Dan Pendidikan Kristiani Peran Guru Dalam Menerapkan Pendidikan Agama Kristen Untuk Menumbuhkan Iman Kristen Anak Sejak Dini." Jurnal Teologi dan Pendidikan Kristiani 1, no. 1 (2020): 14-28.

Novrialdy, Eryzal. "Kecanduan Game Online Pada Remaja: Dampak Dan Pencegahannya." Buletin Psikologi 27, no. 2 (2019): 148 - 158.

Omer, Nopan. "Pentingnya Pendidikan Karakter Dalam Dunia Pendidikan." manager pendidikan 9 (2015): 464468.

Putra, Yanuar Surya. "Theoritical Review : Teori Perbedaan Generasi." Among Makarti 9, no. 2 (2017): 1834.

RG, Salmawaty, dan Hilal Mahmud. "Membentuk Karakter Generasi Muda Melalui Institusi Keluarga Di Era Digital." Kelola: Journal of Islamic Education Management 2, no. 2 (2017): 127-142.

Sawitri, Dara. "Revolusi Industri 4.0 : Big Data Menjawab Tantangan Revolusi Industri 4.0." Jurnal Ilmiah Maksitek 4, no. 3 (2019): 15-27. https://makarioz.sciencemakarioz.or g/index.php/JIM/article/view/83/80.

Tafonao, Talizaro. "Peran Guru Agama Kristen Dalam Membangun Karakter Siswa Di Era Digital." Journal BIJAK Basileia Indonesian Journal of Kadesi 2, no. 1 (2018): 1-37.

Tafonao, Talizaro, Sion Saputra, dan Rosita Suryaningwidi. "Learning Media and Technology: Generation $\mathrm{Z}$ and Alpha." Indonesian Journal of Instructional Media and Model 2, no. 2 (2020): 89-100.

Telaumbanua, Arozatulo. "Peranan Guru Pendidikan Agama Kristen Dalam Membentuk Karakter Siswa." FIDEI: Jurnal Teologi Sistematika dan Praktika 1, no. 2 (2018): 219231.

Telaumbanua, Arozatulo. "Profil Guru Pendidikan Agama Kristen Sebagai Pemimpin Yang Melayai." Jurnal Teruna Bhakti 3, no. 1 (2020): 48.

W, R Willya Achmad, Marcelino Vincentius Poluakan, Didin Dikayuana, Herry Wibowo, dan Santoso Tri Raharjo. "Potret Generasi Milenial Pada Era Revolusi Industri 4.0." Focus: Jurnal Pekerjaan Sosial 2, no. 2 (2020): 187.

Yunarti, Yuyun. "Pendidikan Kearah Pembentukan Karakter." Jurnal Ilmiah Pendidikan 11, no. 2 (2014): 262-278.

Zahroh, Shofiyatuz, dan Na'imah Na'imah. "Peran Lingkungan Sosial Terhadap Pembentukan Karakter Anak Usia Dini Di Jogja Green School." Jurnal PG-PAUD Trunojoyo: Jurnal Pendidikan dan Pembelajaran Anak Usia Dini 7, no. 1 (2020): 1-9.

Zega, Yunardi Kristian. "Pendidikan Agama Kristen Dalam Keluarga: Upaya Membangun Spiritualitas Remaja Generasi Z." Luxnos 7, no. 1 (2021): 105-116.

Zega, Yunardi Kristian. "Teori Perkembangan Iman Remaja Menurut James W.Fowler Dan Implikasinya Bagi Pendidikan Agama Kristen." Jurnal Pendidikan dan Kebudayaan Missio 12, no. 2 (2020): 140-151. 